\title{
Brief History of Early Lithium-Battery Development
}

\author{
Mogalahalli V. Reddy ${ }^{1}{ }^{\oplus}$, Alain Mauger ${ }^{2}$, Christian M. Julien $^{2}{ }^{\infty}$, Andrea Paolella ${ }^{1}$ and \\ Karim Zaghib ${ }^{1, *(1)}$
}

1 Centre of Excellence in Transportation Electrification and Energy Storage (CETEES), Hydro-Québec, 1806, Lionel-Boulet blvd., Varennes, QC J3X 1S1, Canada;

MogalahalliVenkatesh.VenkatashamyReddy@hydro.qc.ca (M.V.R.); paolella.andrea@hydro.qc.ca (A.P.)

2 Institut de Minéralogie, de Physique des Matériaux et de Cosmochimie (IMPMC), Sorbonne Université, UMR-CNRS 7590, 4 Place Jussieu, 75005 Paris, France; alain.mauger@upmc.fr (A.M.); christian.julien@upmc.fr (C.M.J.)

* Correspondence: Zaghib.karim@hydro.qc.ca

Received: 11 March 2020; Accepted: 13 April 2020; Published: 17 April 2020

\begin{abstract}
Lithium batteries are electrochemical devices that are widely used as power sources. This history of their development focuses on the original development of lithium-ion batteries. In particular, we highlight the contributions of Professor Michel Armand related to the electrodes and electrolytes for lithium-ion batteries.
\end{abstract}

Keywords: intercalation compounds; lithium batteries; electrolyte; cathode; anode

\section{Introduction}

Lithium "lithion/lithina" was discovered in 1817 by Arfwedson [1] and Berzelius [2] by analyzing petalite ore $\left(\mathrm{LiAlSi}_{4} \mathrm{O}_{10}\right)$, but the element was isolated through the electrolysis of a lithium oxide by Brande and Davy in 1821 [3]. It was only a century later that Lewis [4] began exploring its electrochemical properties. Considering lithium's excellent physical properties, such as its low density $\left(0.534 \mathrm{~g} \mathrm{~cm}^{-3}\right)$, high specific capacity $\left(3860 \mathrm{mAh} \mathrm{g}^{-1}\right)$, and low redox potential (-3.04 V vs. SHE), it was quickly realized that lithium could serve well as a battery anode.

In early 1958, Harris [5] examined the solubility of lithium in various non-aqueous (aprotic) electrolytes-including cyclic esters (carbonates, $\gamma$-butyrolactone, and $\gamma$-valerolactone), molten salts, and inorganic lithium salt $\left(\mathrm{LiClO}_{4}\right)$ - dissolved in propylene carbonate (PC). He observed the formation of a passivation layer that was capable of preventing a direct chemical reaction between lithium and the electrolyte while still allowing for ionic transport across it, which led to studies on the stability of lithium-ion batteries $[5,6]$. These studies also increased interest in the commercialization of primary lithium-ion batteries.

Since the late 1960s, non-aqueous $3 \mathrm{~V}$ lithium-ion primary batteries have been available in the market with cathodes including lithium sulfur dioxide $\mathrm{Li} / / \mathrm{SO}_{2}$ in 1969 [7]; lithium-polycarbon monofluoride $\left(\mathrm{Li} / /\left(\mathrm{CF}_{\mathrm{x}}\right)_{\mathrm{n}}\right.$ commercialized by Matsushita in 1973 ; lithium-manganese oxide $\left(\mathrm{Li} / / \mathrm{MnO}_{2}\right)$ batteries commercialized by Sanyo company in 1975, initially sold in solar rechargeable calculators (Sanyo, Lithium Battery Calculator, Model CS-8176L); lithium-copper oxide (Li//CuO) batteries still used today [8]; and $\left(\mathrm{Li} / \mathrm{LiI} / \mathrm{Li}_{2} \mathrm{PVP}\right)$ batteries with an $\mathrm{Li}$ metal anode, a lithium iodine electrolyte, and a polyphase cathode of polyvinyl-pyridine (PVP) used in cardiac pacemakers since 1972 (see Holmes [9] for the history of this primary battery). Simultaneously, advances in the understanding of the intercalation of lithium in different materials gave birth to rechargeable (secondary) lithium-ion batteries. In this review, we report a brief history of these secondary batteries that have now taken an important place in our daily life, as we find them in many devices ranging from portable phones to 
electric vehicles. Attention is focused on the beginning of their development in the period of 1970-1990. The contribution of Michel Armand is highlighted in this context.

\section{Intercalation Cathode Development}

In the early 1970s, research was rekindled in the area of the intercalation reactions of an ion, atom, or molecule into a crystal lattice of a host material without destroying the crystal structure. The following general criteria are needed for reversible intercalation reactions: (a) the materials must be crystalline; (b) there must be empty sites in the host crystal lattice in the form of isolated vacancies or as one-dimensional (1D) channels, 2D layers (van der Waals gap), or channels in a 3D network; and (c) both electronic and ionic conductivity must be present for reversible Li intercalation-deintercalation $[10,11]$. Based on these criteria, pioneering intercalation studies on Prussian-blue materials, such as iron cyanide bronzes $\mathrm{M}_{0.5} \mathrm{Fe}(\mathrm{CN})_{3}$, were demonstrated by Armand et al. [12] in 1972. The same year, the topic of energy storage devices and the concept of solid-solution electrodes and electrolyte components for lithium-based secondary batteries were discussed at a NATO conference in Italy, where Brian Steele suggested the use of transition metal disulfides as intercalation electrode materials [13]. Other groups, notably Gamble et al. [14] and Dines et al. [15,16] (EXXON, USA), evaluated transition-metal chalcogenide $\left(M S_{2}\right.$, with $M=\mathrm{Ta}, \mathrm{Nb}$, and Ti) electrode materials. At the same conference, Armand suggested the use of several inorganic materials and transition metal oxides, reported the use of $\mathrm{CrO}_{3}$ within graphitic planes as an electrode material for both $\mathrm{Li}$ and $\mathrm{Na}$ batteries, and described the first solid-state battery using $\beta$-alumina as a solid electrolyte [17].

In 1974, inspired by the pioneering work of Rao et al. [18] (IBM, USA) and the group of Rouxel [19] (Nantes, France) who demonstrated the fast kinetics of the intercalation reactions in metal disulfides, Whittingham patented the $\mathrm{Li}^{2} / \mathrm{TiS}_{2}$ battery $[20,21]$, and the electrochemical properties of $\mathrm{Li}^{0} / / \mathrm{TiS}_{2}$ battery were simultaneously investigated by Whittingham [22] and Winn et al. [23,24] in 1976. One decade later, $\mathrm{Li} / / \mathrm{TiS}_{2}$ cells were commercialized under the form of standard-sized XR2016 coin cells by Eveready Battery Co., USA for CMOS memory back-up applications [25,26], under an AA-sized form by Grace Co., USA with a capacity of 1 Ah [27] and under a C-sized form for a cell operating at temperature in the range of -20 to $+20^{\circ} \mathrm{C}$ with a capacity of $1.6 \mathrm{Ah}$ [28]. Another metal disulfide, namely $\mathrm{MoS}_{2}$, also met success: $\mathrm{Li}^{0} / / \mathrm{MoS}_{2}$ cells (MOLICEL ${ }^{\mathrm{TM}}$ ) were manufactured by Moli Energy Ltd. in Canada, with an energy density of $60-65 \mathrm{Wh} \mathrm{kg}^{-1}$ at a discharge rate of C/3 (800 mA) [29]. Among other metal chalcogenides investigated at that time, only $\mathrm{NbSe}_{3}$ emerged. Following the study of this material as a cathode element by Murphy et al. [30] in 1976, AT\&T (USA) commercialized an AA-sized $\mathrm{Li}^{0} / / \mathrm{NbSe}_{3}$ cylindrical cell operating over 200 cycles at a current of $400 \mathrm{~mA}$ with a capacity of $0.7 \mathrm{Ah}$ in 1989 [31]. For completeness, we mention $\mathrm{V}_{2} \mathrm{O}_{5}$, which was also used as a cathode element of commercialized lithium-ion batteries, but this was only done in the 1990s. Since the present review focuses on the early development of lithium batteries, we guide the reader to a book for further details concerning them [32].

Inspired by the studies on $\mathrm{Na}_{x} \mathrm{CoO}_{2}$ by the group of Hagenmuller [33] in 1973, Goodenough et al. [34] replaced $\mathrm{Na}$ with $\mathrm{Li}$ and proposed $\mathrm{LiCoO}_{2}$ as a new cathode $\left(3.9 \mathrm{~V} \mathrm{vs.} \mathrm{Li}^{+} / \mathrm{Li}\right)$ that they patented in 1979. $\mathrm{LiCoO}_{2}$ is more stable in air than $\mathrm{NaCoO}_{2}$, and its good electrochemical properties [35] have earned it the most commercialized cathode for decades. This result opened up a new approach for research into the development of solid-solution materials, in particular $\mathrm{Li}\left(\mathrm{Ni}_{\mathrm{x}} \mathrm{Mn}_{\mathrm{y}} \mathrm{Co}_{\mathrm{z}}\right) \mathrm{O}_{2}$ (NMC) in the 1990s, as reviewed elsewhere [32].

Early work on spinel $\mathrm{LiMn}_{2} \mathrm{O}_{4}$ was carried out in 1984 by Thackeray et al. [36]. Mn is low cost compared to $\mathrm{Co}$, and the thermal stability of $\mathrm{LiMn}_{2} \mathrm{O}_{4}$ is better than that of $\mathrm{LiCoO}_{2}$. The problem of Mn's dissolution into electrolytes at high temperature, however, was not solved until Zhou et al. found an effective salt, LiFNFSI, which improves resilience [37].

Further advances were made in the development of olivine-based cathodes, and in particular $\mathrm{LiFePO}_{4}$, which was pioneered by the Goodenough's group [38]. The watershed for the use of 
these materials was the discovery of a carbon-coating process discovered in an international lab (France-Québec) directed by Armand (see Ref. [39] and references therein).

$\mathrm{LiFePO}_{4}$ has a remarkable thermal stability, but its redox potential $\left(3.5 \mathrm{~V} \mathrm{vs.} \mathrm{Li}^{+} / \mathrm{Li}\right)$ is small. $\mathrm{LiCoO}_{2}$ has a rather poor stability, but it belongs to the class of $4 \mathrm{~V}$ cathodes. Therefore, in parallel to the development of the $\mathrm{LiFePO}_{4}$ battery, further research was done to improve the thermal stability of $\mathrm{LiCoO}_{2}$ by the synthesis of solid solutions involving doping by $\mathrm{Ni}, \mathrm{Mn}$, and non-transition elements. Early work in 1992 by the group of Delmas et al. [40] suggested a solid-solution concept that was then explored by many groups to optimize the $\mathrm{Li}\left(\mathrm{Ni}_{\mathrm{x}} \mathrm{Mn}_{\mathrm{y}} \mathrm{Co}_{\mathrm{z}}\right) \mathrm{O}_{2}(\mathrm{NMC})$ cathode that is now commercialized by various companies due to its high energy density; it now shares the market with $\mathrm{LiFePO}_{4}$.

\section{Development of Anode Materials}

In addition to the development of positive (cathode) electrode materials, research was also carried out on Li-metal and Li-alloy negative (anode) electrodes. Early batteries were commercialized with such anodes [25-31]. However, they faced safety concerns due to the formation of anode dendrites.

The insertion of lithium in graphite dates from 1955, but this was only confirmed by the synthesis of $\mathrm{LiC}_{6}$ in 1965 [41]. The synthesis of $\mathrm{LiC}_{6}$, however, was not obtained by electrochemical process at that time, and the reversible intercalation of lithium in graphite up to $\mathrm{LiC}_{6}$ was established by Besenhard and Eichinger in 1976 [42,43], but, owing to a lack of a suitable electrolyte that could prevent co-intercalation at that time, graphite was not used as a cathode material. This problem was solved by the group of Armand in 1978 by the use of polymer electrolyte that allowed these authors to identify the suitability of graphite as an intercalated negative electrode [44,45].

In the 1970s, Armand proposed the fabrication of a lithium-ion battery based on two different intercalation materials for both cathodes and anodes; this battery was named the rocking-chair battery (later the lithium-ion battery) due to the shuttle of ions from one electrode to another during the charge-discharge process [46]. This concept involved lithium ions being transferred from one side to the other [45] and was demonstrated in 1980 by Lazzari and Scrosati [47].

The rocking-chair battery concept was thus offered the same year as the $\mathrm{LiCoO}_{2}$ positive electrode was proposed by Goodenough, but the laboratory experiment has to be taken to the industrial scale. This was achieved by the commercialization of the $\mathrm{LiCoO}_{2} / /$ hard-carbon battery by the Sony and Asahi Kasei teams led by Nishi in 1991. The rocking-chair concept later gained major success in the Japanese battery industry with Sony [48] (1985) and Sanyo in 1988 [49].

In the 1990s, another anode material, the spinel $\mathrm{Li}_{4} \mathrm{Ti}_{5} \mathrm{O}_{12}$, was proposed for Li-ion batteries $[50,51]$ and, more recently, for Na-ion batteries [52]. This anode may substitute graphite only when high-power density is needed, but in Na-ion batteries, the $\mathrm{Li}_{4} \mathrm{Ti}_{5} \mathrm{O}_{12}$ electrode delivers a reversible capacity of $155 \mathrm{mAh} \mathrm{g}^{-1}$ and presents the best cycle ability among all reported oxide-based anode materials [53].

\section{Electrolytes}

Armand was a pioneer in the development of a polymer electrolytes based on polyethylene oxide-lithium salts (PEO:Li) [54,55]. Solid-state batteries have the advantage that they use $\mathrm{Li}$ as the anode the collector current. As a result, the theoretical energy density of solid-state batteries is larger than that of Li-ion batteries that use liquid electrolytes. The drawback is that the PEO and polymers in general have a poor ionic conductivity at room temperature, so that the commercial all-solid-state lithium-ion batteries that use polymers, such as the batteries in Bluecars ${ }^{\circledR}$ and Bluebuses ${ }^{\circledR}$, must be used at elevated temperatures. On another hand, liquid electrolytes are very good ionic conductors, and it is difficult to avoid the formation of dendrites at the surface of lithium metal. As a consequence, liquid electrolytes have been adopted in commercial batteries. Such is the case, for instance, for the above-mentioned $\mathrm{LiCoO}_{2}$ battery of Sony that used $\mathrm{LiPF}_{6}$ in propylene carbonate and diethyl carbonate (PC:DEC, 1:1) as the electrolyte. However, PC and DEC are not compatible with lithium metal, so Li-ion batteries with liquid electrolytes adopt the rocking-chair concept with graphite anodes proposed by Armand, implying a smaller theoretical energy density but a higher rate capability at 
room temperature than all-solid-state batteries. The use of graphite, however, implies that PC was commonly used in the first batteries, as its intercalation results in exfoliation of the carbon sheets. Indeed, the Sony $\mathrm{LiCoO}_{2}$-type battery used hard carbon as the anode. The long cycle life of Li-ion batteries with graphitic carbon and liquid electrolytes (without PC) was demonstrated by Basu [56] in 1981, who used a two-molar solution of $\mathrm{LiAsF}_{6}$ dissolved in 1,3 dioxolane. Only in the 1990s, however, did commercialized batteries emerge with a graphite anode using a liquid electrolyte with $\mathrm{LiPF}_{6}$ in carbonate solvents; this is still the standard today.

In 1991, the group of Armand reported a novel salt: lithium bis(trifluoromethanesulfonyl)imide (LiTFSI) [57], now commonly used as an Li-ion conducting electrolytes for Li-ion batteries and later on a new class of single-ion solid polymer [58,59] and solvent-in-salt electrolytes [60], which gives more evidence that Armand was one of the researchers that played a major role in the development of lithium-ion batteries in the period of time covered in this review. Actually, the period of time where he played a major role is continuing. Further details, including the more recent contributions of Armand to the field of electrolytes, were discussed in a recent review [46], but his recent contributions include advanced materials in all components, including electrodes, of lithium- and sodium-ion batteries $[61,62]$.

Prior patents that paved the route to the present Li-ion batteries are reported in Table 1 , and the increase of the energy density of the batteries through the early years of rechargeable batteries is illustrated in Table 2. Note, however, that this figure can only give a partial view of the progress since energy density is not the only parameter that is meaningful. For instance, a battery with an $\mathrm{LiFePO}_{4}$ cathode and a $\mathrm{Li}_{4} \mathrm{Ti}_{5} \mathrm{O}_{12}$ anode can be cycled over 30,000 cycles at very fast rate of $15 \mathrm{C}$ (4 min) and a discharge rate of $5 \mathrm{C}(12 \mathrm{~min})$ [63]. This performance gives interest to such a battery for some applications, even though its energy density is smaller than that of the $\mathrm{LiFePO}_{4}$-graphite battery, since the operating voltage of the battery is reduced by $1.5 \mathrm{~V}$.

Table 1. List of some of patents related to the early lithium-ion batteries.

\begin{tabular}{|c|c|c|c|}
\hline Inventor/Company & Patent Title & $\begin{array}{l}\text { Patent } \\
\text { Number }\end{array}$ & $\begin{array}{l}\text { Application } \\
\text { Date }\end{array}$ \\
\hline $\begin{array}{l}\text { Armand, M.; Duclot, M. } \\
\text { (ANVAR, France) }\end{array}$ & See Reference [44] & $\begin{array}{l}\text { French } \\
7,832,976\end{array}$ & 22 Nov. 1978 \\
\hline $\begin{array}{l}\text { Goodenough, J.B.; Mizushima, K. } \\
\text { (UK Atomic Energy Establishment) }\end{array}$ & $\begin{array}{l}\text { Fast ion conductors } \\
\qquad\left(\mathrm{A}_{\mathrm{x}} \mathrm{M}_{\mathrm{y}} \mathrm{O}_{2}\right)\end{array}$ & $\begin{array}{c}\text { U.S. } \\
4,357,215 \mathrm{~A}\end{array}$ & 5 April 1979 \\
\hline $\begin{array}{l}\text { Goodenough, J.B.; Mizushima, K. } \\
\text { (UK Atomic Energy Establishment) }\end{array}$ & $\begin{array}{l}\text { Electrochemical cell with } \\
\text { new fast ion conductors }\end{array}$ & $\begin{array}{l}\text { U.S. } \\
4,302,518\end{array}$ & 31 March 1980 \\
\hline Basu, S. (Bell Labs Inc., USA) & Graphite/Li in molten salt & $\begin{array}{c}\text { U.S. } \\
4,304,825\end{array}$ & 21 Nov. 1980 \\
\hline $\begin{array}{l}\text { Armand, M.; Duclot, M. } \\
\text { (ANVAR, France) }\end{array}$ & See Reference [43] & $\begin{array}{c}\text { U.S. } \\
4,303,748\end{array}$ & 12 Jan. 1981 \\
\hline $\begin{array}{c}\text { Ikeda, H.; Narukawa, K.; Nakashima, H. } \\
\text { (Sanyo Co., Japan) }\end{array}$ & $\begin{array}{l}\text { Graphite/Li in nonaqueous } \\
\text { solvents }\end{array}$ & $\begin{array}{l}\text { Japanese } \\
1,769,661\end{array}$ & 18 June 1981 \\
\hline Basu S. (Bell Labs Inc., USA) & $\begin{array}{l}\text { Graphite/Li in nonaqueous } \\
\text { solvents }\end{array}$ & $\begin{array}{c}\text { U.S. } \\
4,423,125 \mathrm{~A}\end{array}$ & 13 Sept. 1982 \\
\hline $\begin{array}{l}\text { Yoshino, A.; Jitsuchika, K.; Nakajima, T. } \\
\text { (Asahi Chemical Ind., Japan) }\end{array}$ & $\begin{array}{l}\text { Li-ion battery based on } \\
\text { carbonaceous material }\end{array}$ & $\begin{array}{l}\text { Japanese } \\
1,989,293\end{array}$ & 5 Oct. 1985 \\
\hline $\begin{array}{l}\text { Nishi N., Azuma H., Omaru A. } \\
\text { (Sony Corporation) }\end{array}$ & Non aqueous electrolyte cell & $\begin{array}{c}\text { U.S. } \\
4,959,281\end{array}$ & 29 Aug. 1989 \\
\hline $\begin{array}{c}\text { Fujimoto, M.; Yoshinaga, N.; Ueno, K. } \\
\text { (Japan) }\end{array}$ & Li-ion secondary batteries & $\begin{array}{l}\text { Japanese } \\
3,229,635\end{array}$ & Nov. 1991 \\
\hline
\end{tabular}


Table 2. Table of the main early rechargeable lithium batteries that were commercialized before 1991 . Note that they all have a lithium metal anode, with the first lithium-ion battery with a carbon anode dating to 1991 and the rocking chair concept (Michel Armand) dating to 1970.

\begin{tabular}{ccccc}
\hline $\begin{array}{c}\text { Electrochemical } \\
\text { System }\end{array}$ & $\begin{array}{c}\text { Voltage } \\
\text { (V) }\end{array}$ & $\begin{array}{c}\text { Specific Energy } \\
\text { Wh/kg }\end{array}$ & Wh/L & Commercial Co. (Issue) \\
\hline $\mathrm{Li} / / \mathrm{TiS}_{2}$ & 2.1 & 130 & 280 & Exxon (1978) \\
$\mathrm{Li} / / \mathrm{LiAlCl}_{4}-\mathrm{SO}_{2}$ & 3.2 & 63 & 208 & Duracell (1981) \\
$\mathrm{Li} / / \mathrm{NbSe}_{3}$ & 2.0 & 95 & 250 & Bell Telephone Lab. Inc. (1983) \\
$\mathrm{LiAl} / /$ polyaniline & 3.0 & - & 180 & Bridgestone (1987) \\
$\mathrm{Li} / / \mathrm{MoS}_{2}$ & 1.8 & 52 & 140 & MoLi Energy (1987) \\
$\mathrm{Li} / / \mathrm{V}_{2} \mathrm{O}_{5}$ & 1.5 & 10 & 40 & Toshiba (1989) \\
$\mathrm{LiAl} / / \mathrm{polypyrolle}$ & 3.0 & - & 180 & Kanebo (1989) \\
$\mathrm{Li} / / \mathrm{Li}_{0.3} \mathrm{MnO}_{2}$ & 3.0 & 50 & 140 & Tadiran (1989) \\
$\mathrm{LiVO}_{\mathbf{x}}$ & 3.2 & 200 & 300 & Hydro-Québec $(1990)$ \\
$\mathrm{C} / / \mathrm{LiCoO}_{2}$ & 3.6 & $150-190$ & - & Sony (1991) \\
\hline
\end{tabular}

The stability of different electrolytes and the Li-polymer cell architecture proposed by Professor Michel Armand are illustrated in Figure 1. The sequence of stability ranges in the order cyclic carbonates (SEI zone) < polyethylene oxide $(\mathrm{PEO})<$ molten salts.

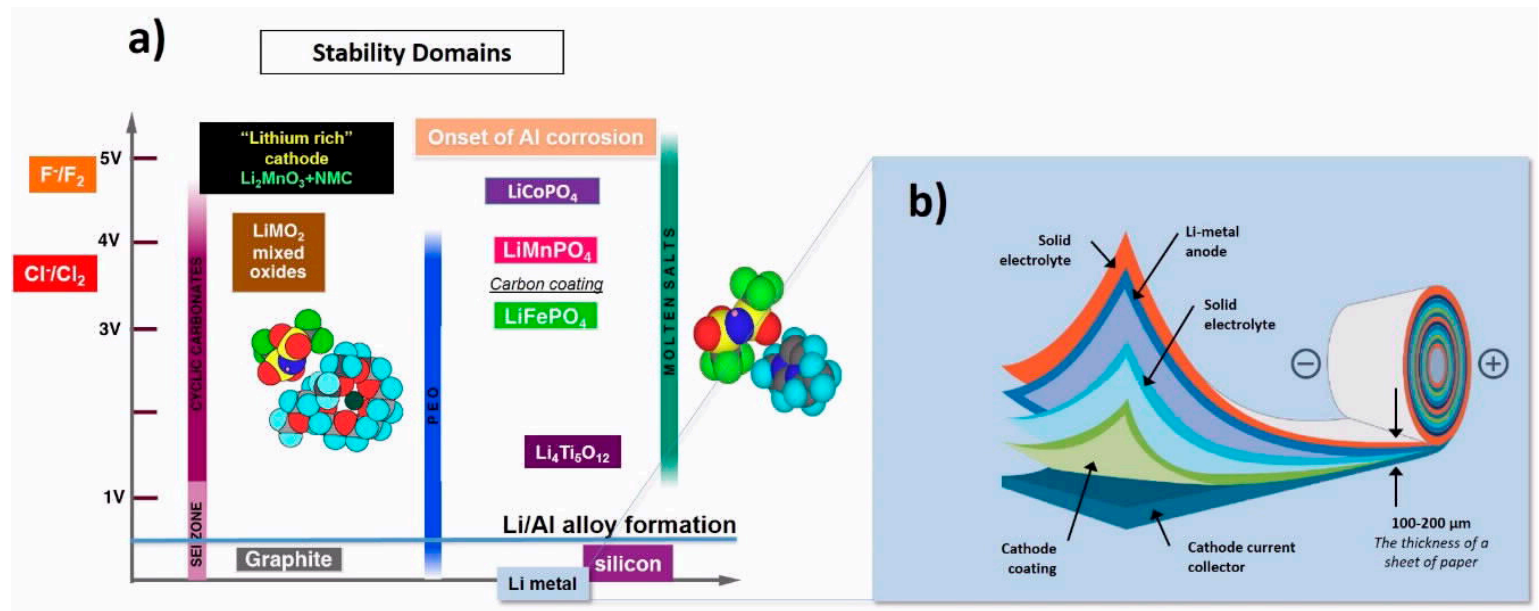

Figure 1. (a) Stability of different electrolytes and (b) solid state lithium metal polymer battery architecture proposed by Professor Michel Armand.

\section{Separators}

For completeness, we mention the separator, which is the last important component of lithium-ion batteries. This element, however, has raised much less trouble than electrodes and electrolytes. As soon as 1970, a time where lithium metal was used as the anode of primary batteries with organic electrolytes, prototype models of Li//CuS cells had been developed by SAFT in France in a pilot line type of operation [64-66], using a non-woven polypropylene separator. The $\mathrm{Li} / / \mathrm{V}_{2} \mathrm{O}_{5}$ system patented by Livingston Electronic Corporation (now Honeywell) [6] and P. R. Mallory and Co. Inc. [67,68] used a cellulosic separator, e.g., filter paper or a Celgard ${ }^{\circledR}$ separator of porous polypropylene. Another example is the $\mathrm{Li} / / \mathrm{SO}_{2}$ system [69]. Actually, most of the lithium metal batteries developed in the early 1970s already used a non-woven polypropylene separator. The alternative was a glass-fiber paper separator, like in the case of the $\mathrm{Li} / / \mathrm{SOCl}_{2}$ cell [70].

\section{Conclusions}

Fundamental works on lithium-ion batteries date from the 1970s, and remarkable progress has been made since the 1980s. The first commercial lithium-ion battery was issued in 1991, making it a 
rather short period of time between work in laboratories and the industrial production. In this review, we reported the main steps that led to this success. Among the people that contributed to this success from this beginning up to now, Michel Armand has played a key role in the creation and development of lithium-ion battery cathodes, anodes, and electrolytes. We deem him to be one of the "forefathers of modern batteries," inspiring many academic and industrial researchers to design alternative electrode and electrolyte materials with high energy densities, long cycle lives, and low costs, leading to the further development of the batteries for electric vehicles and for the regulation of the current produced by intermittent sources before integration into smart grids.

Author Contributions: Conceptualization, K.Z.; writing-original draft preparation, M.V.R. and A.P.; writing-review and editing, A.M. and C.M.J. All authors have read and agreed to the published version of the manuscript.

Funding: This research received no external funding.

Acknowledgments: The authors thank John B. Goodenough for helpful comments.

Conflicts of Interest: The authors declare no conflict of interest.

\section{References}

1. Arfwedson, J.A. Untersuchung einiger bei der eisen-grube von utö vorkommenden fossilien und von einem darin gefundenen neuen feuerfesten alkali. J. Chem. Phys. 1818, 22, 93-117.

2. Berzelius, J.J. Ein neues mineralisches alkali und ein neues metall. J. Chem. Phys. 1817, 21, 44-48.

3. Brande, W.T. A Manual of Chemistry, 2nd ed.; John Murray: London, UK, 1821; Volume 2, pp. 57-58.

4. Lewis, G.N.; Keyes, F.G. The potential of the lithium electrode. J. Am. Chem. Soc. 1913, 35, 340-344. [CrossRef]

5. Harris, W.S. Electrochemical Studies in Cyclic Esters. Ph.D. Thesis, Univ. California, Berkeley, CA, USA, 1958.

6. Jasinski, J. High Energy Batteries; Plenum: New York, NY, USA, 1967.

7. Meyers, W.F.; Simmons, J.W. Electric Current-Producing Cell with Anhydrous Organic Liquid Electrolyte. U.S. Patent 3,423,242, 21 January 1969.

8. Goodenough, J.B. Battery components, active materials for. In Batteries for Sustainibility: Selected Entries from the Encyclopedia of Sustainibility Science and Technology; Brodd, R.J., Ed.; Springer Sci.: New York, NY, USA, 2013; pp. 51-92.

9. Holmes, C.F. The lithium/iodine-polyvinyl-pyrolidine battery-35 years of successful clinical use. ECS Trans. 2007, 6, 1-7.

10. Armand, M.; Touzain, P. Graphite intercalation compounds as cathode materials. Mater. Sci. Eng. 1977, 31, 319-329. [CrossRef]

11. Armand, M.B. Intercalation electrodes. In Materials for Advanced Batteries; Murphy, D.W., Broadhead, J., Steele, B.C.H., Eds.; Springer: New York, NY, USA, 1980; pp. 145-161.

12. Armand, M.B.; Whittingham, M.S.; Huggins, R.A. The iron cyanide bronzes. Mater. Res. Bull. 1972, 7 , 101-107. [CrossRef]

13. Steele, B.C.H. Chemical diffusion. In Fast Ion Transport in Solids: Solid State Batteries and Devices; van Gool, W., Ed.; North Holland Publ.: Amsterdam, The Netherlands, 1973; pp. 103-122.

14. Gamble, F.R.; Osiecki, J.H.; Cais, M.; Plsharody, R.; DiSalvo, F.J.; Geballe, T.H. Intercalation complexes of Lewis bases and layered sulfides: A large class of new superconductors. Science 1971, 174, 493-497. [CrossRef]

15. Dines, M.B. Intercalation of metallocenes in the layered transition-metal dichalcogenides. Science 1975, 188, 1210-1211. [CrossRef] [PubMed]

16. Dines, M.B. Lithium intercalation via n-butyllithium of the layered transition metal dichalcogenides. Mater. Res. Bull. 1975, 10, 287-291. [CrossRef]

17. Armand, M. Lithium intercalation in $\mathrm{CrO}_{3}$ using n-butyllithium. In Fast Ion Transport in Solids: Solid State Batteries and Devices; van Gool, W., Ed.; North Holland Publ.: Amsterdam, The Netherlands, 1973; pp. 665-673. 
18. Rao, G.V.S.; Tsang, J.C. Electrolysis method of intercalation of layered transition metal dichalcogenides. Mater. Res. Bull. 1974, 9, 921-926. [CrossRef]

19. Leblanc-Soreau, A.; Danot, M.; Trichet, L.; Rouxel, J. Les intercalaires $\mathrm{A}_{\mathrm{x}} \mathrm{TiS}_{2}$ et $\mathrm{A}_{\mathrm{x}} \mathrm{ZrS} \mathrm{S}_{2}$. Structure et liaisons (A = Li, Na, K, Rb, Cs). Mater. Res. Bull. 1974, 9, 191-197. [CrossRef]

20. Whittingham, M.S. Batteries à Base de Chalcogénures. Belgian Patent 819,672, 10 March 1975.

21. Whittingham, M.S. Chalcogenide Batteries. U.S. Patent 4,009,052, 22 February 1977.

22. Whittingham, M.S. Electrical energy storage and intercalation chemistry. Science 1976, 192, $1126-1127$. [CrossRef] [PubMed]

23. Winn, D.A.; Shemilt, J.M.; Steele, B.C.H. Titanium disulphide: A solid solution electrode for sodium and lithium. Mater. Res. Bull. 1976, 11, 559-566. [CrossRef]

24. Winn, D.A.; Steele, B.C.H. Thermodynamic characterisation of non-stoichiometric titanium di-sulphide. Mater. Res. Bull. 1976, 11, 551-557. [CrossRef]

25. Akridge, J.R.; Vourlis, H. Solid state batteries using vitreous solid electrolytes. Solid State Ion. 1986, 18-19, 1082-1087. [CrossRef]

26. Akridge, J.R.; Vourlis, H. Performance of the $\mathrm{Li} / \mathrm{TiS}_{2}$ solid state batteries using phosphorous chalcogenide network former glasses as solid electrolyte. Solid State Ion. 1988, 28-30, 841-846. [CrossRef]

27. Anderman, M.; Lundquist, J.T.; Johnson, S.L.; Giovannoni, R.T. Rechargeable lithium-titanium disulphide cells of spirally-wound design. J. Power Sources 1989, 26, 309-312. [CrossRef]

28. Abraham, K.M.; Pasquariello, D.M.; Schwartz, D.A. Practical rechargeable lithium batteries. J. Power Sources 1989, 26, 247-255. [CrossRef]

29. Py, M.A.; Haering, R.R. Structural destabilization induced by lithium intercalation in $\mathrm{MoS}_{2}$ and related compounds. Can. J. Phys. 1983, 61, 76-84. [CrossRef]

30. Murphy, D.W.; Trumbore, F.A. The chemistry of $\mathrm{TiS}_{3}$ and $\mathrm{NbSe}_{3}$ cathodes. J. Electrochem. Soc. 1976, 123, 960-964. [CrossRef]

31. Trumbore, F.A. Nobium triselenide: A unique rechargeable positive electrode material. J. Power Sources 1989, 26, 65-75. [CrossRef]

32. Julien, C.M.; Mauger, A.; Vijh, A.; Zaghib, K. Lithium Batteries: Science and Technology; Springer: Cham, Switzerland, 2016; pp. 1-619.

33. Fouassier, C.; Matejka, G.; Reau, J.M.; Hagenmuller, P. Sur de nouveaux bronzes oxygénés de formule $\mathrm{Na}_{\chi} \mathrm{CoO}_{2}(\chi 1)$. Le système cobalt-oxygène-sodium. J. Solid State Chem. 1973, 6, 532-537. [CrossRef]

34. Goodenough, J.B.; Mizushima, K.; Wiseman, P.J. Electrochemical Cell and Method of Making Ion Conductors for Said Cell. Eur. Patent EP0017400A1, 5 April 1979.

35. Mizushima, K.; Jones, P.C.; Wiseman, P.J.; Goodenough, J.B. $\mathrm{Li}_{x} \mathrm{CoO}_{2}(0 \geq \mathrm{x} \geq-1)$ : A new cathode material for batteries of high energy density. Mater. Res. Bull. 1980, 15, 783-789. [CrossRef]

36. Thackeray, M.M.; Johnson, P.J.; Depicciotto, L.A.; Bruce, P.G.; Goodenough, J.B. Electrochemical extraction of lithium from $\mathrm{LiMn}_{2} \mathrm{O}_{4}$. Mater. Res. Bull. 1984, 19, 179-187. [CrossRef]

37. Zhou, S.; Han, H.; Nie, J.; Armand, M.; Zhou, Z.; Huang, X. Improving the high-temperature resilience of $\mathrm{LiMn}_{2} \mathrm{O}_{4}$ based batteries: LiFNFSI an effective salt. J. Electrochem. Soc. 2012, 159, A1158-A1164. [CrossRef]

38. Padhi, A.K.; Nanjundaswamy, K.S.; Goodenough, J.B. Phospho-olivines as positive-electrode materials for rechargeable lithium batteries. J. Electrochem. Soc. 1997, 144, 1188-1194. [CrossRef]

39. Ravet, N.; Gauthier, M.; Zaghib, K.; Mauger, A.; Goodenough, J.; Gendron, F.; Julien, C.M. Mechanism of the $\mathrm{Fe}^{2+}$ reduction at low temperature, for $\mathrm{LiFePO}_{4}$ synthesis from a polymer additive. Chem. Mater. 1970, 19, 2595-2602. [CrossRef]

40. Delmas, C.; Saadoune, I. Electrochemical and physical properties of the $\mathrm{Li}_{\mathrm{x}} \mathrm{Ni}_{1-\mathrm{y}} \mathrm{Co}_{\mathrm{y}} \mathrm{O}_{2}$ phases. Solid State Ion. 1992, 53-56, 370-375.

41. Guérard, D.; Hérold, A. Intercalation of lithium into graphite and other carbons. Carbon 1975, 13, 337-345. [CrossRef]

42. Besenhard, J.O.; Eichinger, G. High energy density lithium cells: Part I. Electrolytes and anodes. J. Electroanal. Chem. 1976, 68, 1-18. [CrossRef] 
43. Eichinger, G.; Besenhard, J.O. High energy density lithium cells: Part II. Cathodes and complete cells. J. Electroanal. Chem. 1976, 72, 1-31. [CrossRef]

44. Armand, M.; Duclot, M. Electrochemical Generators for Producing Current and New Materials for Their Manufacture. U.S. Patent 4,303,748, 12 January 1981.

45. Armand, M.; Duclot, M. Ionically and Pref. Electronically Conductive Electrode—Comprising Agglomerate of Active Electrode Material and Solid Soln. of Ionic Cpd. in Polymer Pref. Polyoxyalkylene. French Patent 7,832,976, 22 November 1978.

46. Mauger, A.; Julien, C.M.; Goodenough, J.B.; Zaghib, K. Tribute to Michel Armand: From rocking chair-Li-ion to solid-state lithium batteries. J. Electrochem. Soc. 2019, 167, 070507. [CrossRef]

47. Lazzari, M.; Scrosati, B. A Cyclable lithium organic electrolyte cell based on two intercalation electrodes. J. Electrochem. Soc. 1980, 127, 773-774. [CrossRef]

48. Nagaura, T.; Nagamine, M.; Tanabe, I.; Miyamoto, N. Solid-state batteries with sulfide-based electrolytes. Prog. Batteries Sol. Cells 1989, 8, 84-88.

49. Nagaura, T.; Tozawa, K. Lithium-ion rechargeable battery. Prog. Batteries Sol. Cells 1990, 9, $209-212$.

50. Ferg, E.; Gummow, R.J.; Decock, A.; Tackeray, M.M. Spinel anodes for lithium-ion rechargeable batteries. J. Electrochem. Soc. 1994, 141, L147-L150. [CrossRef]

51. Ohzuku, T.; Ueda, A.; Yamamoto, N. Zero-strain insertion material of $\mathrm{Li}\left[\mathrm{Li}_{1 / 3} \mathrm{Ti}_{5 / 3}\right] \mathrm{O}_{4}$ for rechargeable lithium cells. J. Electrochem. Soc. 1995, 142, 1431-1435. [CrossRef]

52. Zhao, L.; Pan, H.L.; Hu, Y.S.; Li, H.; Chen, L.Q. Spinel lithium titanate $\left(\mathrm{Li}_{4} \mathrm{Ti}_{5} \mathrm{O}_{12}\right)$ as novel anode material for room-temperature sodium-ion battery. Chin. Phys. B 2012, 21, 028201. [CrossRef]

53. Sun, Y.; Zhao, L.; Pan, H.; Gu, L.; Hu, Y.-S.; Li, H.; Armand, M.; Ikuhara, Y.; Chen, L.; Huang, X. Direct atomic-scale confirmation of three-phase storage mechanism in $\mathrm{Li}_{4} \mathrm{Ti}_{5} \mathrm{O}_{12}$ anodes for room-temperature sodium-ion batteries. Nat. Commun. 2013, 4, 1870. [CrossRef]

54. Armand, M.B.; Duclos, M.J.; Rigaud, P. Polymer solid electrolytes: Stability domain. Solid State Ion. 1981, 3-4, 429-430. [CrossRef]

55. Armand, M.B. Polymer solid electrolytes-An overview. Solid State Ion. 1983, 9-10, 745-754. [CrossRef]

56. Basu, S. Graphite/Li in Nonaqueous Solvents. U.S. Patent 4,423,125, 13 September 1982.

57. Callens, S.; Le Nest, J.F.; Gandini, A.; Armand, M. A novel solid polymer electrolyte: Synthesis and characterization. Polym. Bull. 1991, 25, 443-450. [CrossRef]

58. Bouchet, R.; Maria, S.; Meziane, R.; Aboulaich, A.; Lienafa, L.; Bonnet, J.P.; Phan, T.N.T.; Bertin, D.; Gigmes, D.; Devaux, D.; et al. Single-ion BAB triblock copolymers as highly efficient electrolytes for lithium-metal batteries. Nat. Mater. 2013, 12, 452-457. [CrossRef] [PubMed]

59. Zhou, D.; Shanmukaraj, D.; Tkacheva, A.; Armand, M.; Wang, G. Polymer electrolytes for lithium-based batteries: Advances and prospects. Chem 2019, 5, 2326-2352. [CrossRef]

60. Suo, L.; Hu, Y.S.; Li, H.; Armand, M.; Chen, L. A new class of solvent-in-salt electrolyte for high-energy rechargeable metallic lithium batteries. Nat. Commun. 2013, 4, 1481. [CrossRef] [PubMed]

61. Zhang, H.; Armand, M.; Rojo, T. Review-innovative polymeric materials for better rechargeable batteries: Strategies from CIC Energigune. J. Electrochem. Soc. 2019, 166, A679-A686. [CrossRef]

62. Mauger, A.; Julien, C.; Paolella, A.; Armand, M.; Zaghib, K. Recent progress on organic electrodes materials for rechargeable batteries and supercapacitors. Materials (Basel) 2019, 12, 1770. [CrossRef]

63. Zaghib, K.; Dontigny, M.; Guerfi, A.; Charest, P.; Mauger, A.; Julien, C.M. Safe and fast charging Li-ion battery with long shelf life for power applications. J. Power Sources 2011, 196, 3949-3954. [CrossRef]

64. Gabano, J.B. Electrochemical Generator with Non-Aqueous Electrolyte. U.S. Patent 3,542,601, 24 November 1970.

65. Gabano, J.B.; Gerbier, G. Electrochemical Generator Utilizing a Lithium Anode, Copper Sulfide Cathode and Non-Aqueous Electrolytes. U.S. Patent 3,511,716, 12 May 1970.

66. Gabano, J.B.; Dechenaux, V.; Gerbier, G.; Jammet, J. D-size lithium cupric sulfide cells. J. Electrochem. Soc. 1972, 119, 459. [CrossRef]

67. Dey, A.N.; Sullivan, B.P. Method of Preparing Cathodic Electrodes. U.S. Patent 3,655,585, 11 April 1972.

68. Dey, A.N.; Sullivan, B.P. Mixed Solvents for High and Low Temperature Organic Electrolyte Batteries. U.S. Patent 3,947,289, 30 March 1976. 
69. Maricle, D.L.; Mohns, J.P. Electrochemical Cell Containing Sulfur Dioxide as the Cathode Depolarizer. U.S. Patent 3,567,515, 2 March 1971.

70. Dey, A.N. Primary Li/SOCl 2 Cells-I. Performance characteristics of hermetically sealed D cells. Electrochim. Acta 1976, 21, 855-860. [CrossRef]

(C) 2020 by the authors. Licensee MDPI, Basel, Switzerland. This article is an open access article distributed under the terms and conditions of the Creative Commons Attribution (CC BY) license (http://creativecommons.org/licenses/by/4.0/). 